\title{
Double-Skin Facades with Semi-Transparent Modules for Building Retrofit Actions: Energy and Visual Performances
}

\author{
Michelangelo Scorpio, Giovanni Ciampi, Yorgos Spanodimitriou, Roberta Laffi, \\ Antonio Rosato, Sergio Sibilio \\ University of Campania Luigi Vanvitelli, Department of Architecture and Industrial Design, \\ Aversa, Italy
}

\begin{abstract}
The performances and the optimal configuration of new semi-transparent modules for Double-Skin Façade are investigated through the dynamic simulation software TRNSYS and Radiance. A sensitivity analysis is conducted upon varying the: (i) material typology, (ii) cavity depth and (iii) transparency of the materials used for the modules. The analysis highlights that, in comparison with the base case without Double-Skin Façade, the new modules can improve energy efficiency of buildings and indoor environmental quality. The analysis underlines also that the performances and the optimal configuration are strongly dependent on the boundary conditions as well as the material thermal and visual characteristics.
\end{abstract}

\section{Introduction}

Taking control over the external conditions while bringing effective benefits in the indoor environment is a crucial problem in the architectural design process, especially today as the trends go to a widespread use of glazing façades and the market presents every day more and more solutions able to replace traditional materials and techniques.

In this panorama, the building envelope becomes the first point to be investigated, along with the assessment of the new solutions behaviour.

The envelope embodies the building appearance itself, while also providing important functions (Atzeri et al., 2016; Kuhn, 2017), such as visual continuity with the exteriors, daylight and solar gain control and glare protection, which contribute to achieve a comfortable and healthy indoor environment as well as a good building energy efficiency.

The commonly used high-glass ratio façade often suffers from inhomogeneities in the internal light distributions, as well as glare and overheating, with the last one especially due to the like-hood of greenhouse effect in the building itself. These problems of course are reflected in an increased energy consumption to reach and maintain an acceptable indoor comfort level.

To overcome these inefficiencies, the contemporary architecture trend is leaning more and more towards a wide use of Double-Skin Façades (DSFs), thanks to their clean and modern look and energy-saving ability (Hoseini et al., 2016). However, the wide-range of possible solutions, coming from different ventilation strategies, different glazing's characteristics, different shadings and cavity's configurations (Barbosa and Ip, 2014), worsen the problem to effectively predict the behaviour of this technology, especially if the use of innovative materials is added to the equation. In spite of these possible variations, the DSFs still result as a viable option, as confirmed by studies such the one from Pomponi et al. (2016), which reviewed fifty DSF systems in temperate climates, showing a potential reduction of $90 \%$ for the heating loads and $30 \%$ for the cooling loads. Moreover, the interposition of an appropriate shading device or material could further reduce the cooling load (Baldinelli, 2009; Gratia and De Herde, 2007).

In addition to DSF systems, new solutions comprehend the utilization of materials as plastic to improve the characteristics of new or existent façades. Plastic materials offer a lightweight and low-cost alternative to all-glass systems. While initially these materials where prone to discoloration and bad weather resistance, the growth in the variety produced a market scenario where is possible to find plastics with good/very good life-span, quality and resistance. Among these, there are some already quite used and studied solutions, as the ETFE (ethylene tetrafluoroethylene) which offers modulable light transmission and design flexibility (Mainini et al., 2014; Mainini et al., 2016; Ahadi et al., 2016; Peach, 2016) also in comparison with glass (Cremers, 2014; Monticelli et al., 2009). Moreover, the literature review underlines that ETFE is mostly used as air-filled cushions for claddings and roofs of buildings. Other materials instead, such as plastic fabrics and ETFE white, being more recent or less adopted, still have to be truly approached, lacking models' representative of their physical behaviours. Therefore, to aid and improve the future architectural design, there is a need to develop simulation models able to represent the behaviour of these complex systems.

The main objectives of this research are: i) the modelling of these new materials (especially for ETFE white and plastic fabric) and ii) the on-site assessment of the proposed solutions as second skin of a ventilated façade. Indeed, this work is a starting point in the development of comprehensive simulation models which integrate the aforementioned materials, ETFE and plastic fabric, into a DSF system.

The aim is to start to investigate how a combined system behaves from a daylighting and energy points of view. 
So, a sensitivity analysis is conducted by means of the dynamic simulation software TRNSYS 17, coupled with the software Radiance to assess the daylighting contribution, upon varying the: (i) material typology (Plastic Fabric, ETFE, ETFE white), (ii) cavity depth $(0.05 \mathrm{~m}$ and $0.10 \mathrm{~m})$ and (iii) transparency $(90.4 \%, 33 \%$ and $25.8 \%$ ) of the materials used for these modules. Then, the simulation results are compared in terms of heating and cooling energy demand reduction, Primary Energy Saving (PES), $\mathrm{CO}_{2}$ equivalent emission avoided, Useful Daylight Illuminance (UDI) and Spatial Daylight Autonomy (sDA), in order to define the optimal configuration and identify the system able to ensure the best performance.

\section{Simulation models}

The analysis is carried out by considering a sample room (test facility), $2.20 \mathrm{~m}$ width for $2.80 \mathrm{~m}$ deep and $2.40 \mathrm{~m}$ tall, with a window $1.50 \mathrm{~m}$ wide for $1.80 \mathrm{~m}$ tall centred in the South wall. The models are realized on the SketchUp 3D drawing software and then exported by means of two different plugins, Trnsys3D and Su2rad, for thermal and visual simulations. Figure 1 shows the test facility simulation model without (used as reference) and equipped with the DSF.

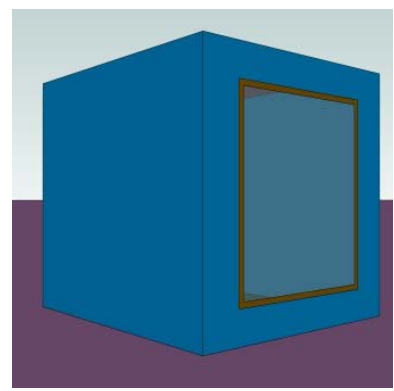

a)

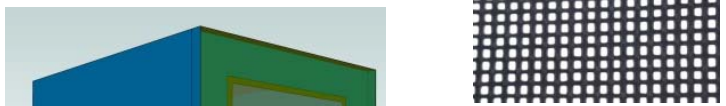

a)

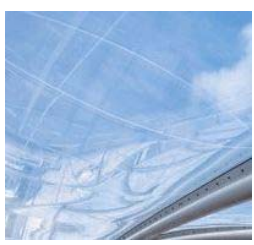

b)

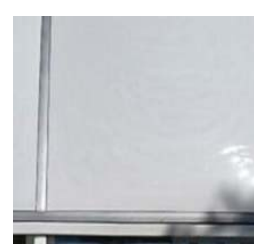

c)
Figure 2: Semi-transparent materials used to develop the new modules for DSFs: a) Plastic Fabric, b) ETFE and c) ETFE white.

The "trans" material model considers the glazing as a perfect Lambertian diffuser and assumes the solar visible transmittance constant for different light incident angles. The two plastic materials are simulated setting the amount of light transmitted as totally direct for ETFE and totally diffuse for ETFE white. From the thermal point of view, they are modelled using the software WINDOWS 7.5. The ETFE layer is modelled in WINDOWS 7.5 as a single glass considering the manufacturer data. In particular, two different models of ETFE are developed, one for the clear $\left(\tau_{\mathrm{sol}}=90.4 \%\right)$ and another for the milky $\left(\tau_{\mathrm{sol}}=25.8 \%\right)$. Both clear and milky ETFE models have a thermal conductivity equal to $0.238 \mathrm{~W} / \mathrm{mK}$ and a thickness of 250 $\mu \mathrm{m}$. The report of the software calculation is then exported in DOE-2 style, enlisted inside the W4LIB.DAT and the PRGWIN.DAT files, which contain the database of all the fenestration systems used in TRNSYS. In this work, component modules (called "Types" in TRNSYS terminology) are selected from the TRNSYS libraries and enhanced by manufactures performance data or information available in current scientific literature according to the common characteristics of the components used in practice prior to performing the simulations. 
From the thermal point of view, the approach followed for modelling the DSF, realised with semi-transparent materials, consists of considering the cavity as an additional thermal zone adjacent to the thermal zone modelling the test cell. Both the thermal zones are modelled by means the "Type 56". This "Type" uses the temperature of the surfaces bordering the thermal zones to determine the temperature of the air inside each zone. Then the air flow within the additional thermal zone is computed through TRNBuild.

In particular, as reported in Figure 3, this additional thermal zone is characterised by having: i) the South wall as well as both the bottom and top walls fully glazed and ii) the East and West walls with the same thermal characteristics of the test cell opaque walls. The windows on the bottom and top walls are modelled as constantly open, while the window on the South wall is modelled to reproduce the same thermal behaviour of the materials used as second-skin.

1. Test cell thermal zone

2. Additional thermal zone (DSF)

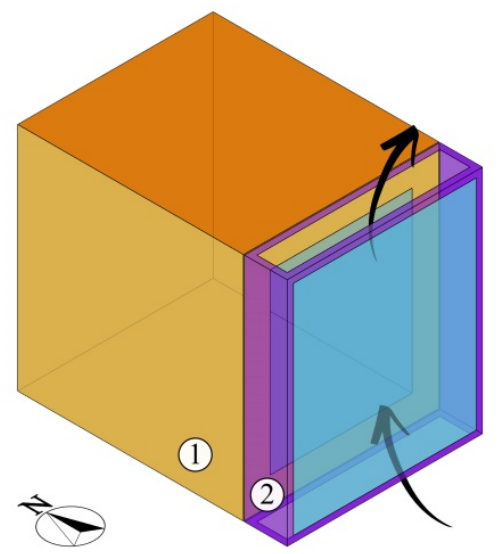

Figure 3: Schematic view of the two thermal zones used to model both the test cell and DSF.

The plastic fabric, because of its complex behaviour, proved to be best represented by a geometrical model instead, so it was 3D modelled back in the drawing software, on the basis of the declared porosity percentage of $33 \%$, and then simulated as a shading object from the thermal and the visual points of view.

Finally, TRNSYS and Radiance where coupled by means of "Type DLT" (De Michele et al., 2014), in order to carry out thermal and daylight simulation in unison. So as to evaluate the effect of different boundary conditions on the performances and the optimal configuration of the new modules, two months are considered for simulations, January for the winter and July for the summer. The simulations are carried out with a timestep of 1 hour across the whole months.

Table 1 shows the summary of all simulation cases examined in this paper, with information about the module material, the cavity depth and the simulation month.
Table 1: Simulation cases.

\begin{tabular}{|c|c|c|c|}
\hline $\begin{array}{c}\text { Simulation } \\
\text { case }\end{array}$ & $\begin{array}{c}\text { Material of } \\
\text { the DSF } \\
\text { shading layer }\end{array}$ & $\begin{array}{l}\text { Cavity } \\
\text { Depth } \\
\text { (m) }\end{array}$ & $\begin{array}{l}\text { Simulation } \\
\text { month }\end{array}$ \\
\hline Case 0 & without DSF & - & \multirow{7}{*}{$\begin{array}{c}\text { January } \\
\text { and } \\
\text { July }\end{array}$} \\
\hline Case 1 & Plastic Fabric & 0.05 & \\
\hline Case 2 & Plastic Fabric & 0.10 & \\
\hline Case 3 & ETFE & 0.05 & \\
\hline Case 4 & ETFE & 0.10 & \\
\hline Case 5 & ETFE white & 0.05 & \\
\hline Case 6 & ETFE white & 0.10 & \\
\hline
\end{tabular}

In all the cases, the sensors are set up as follow: for the temperatures' trend, the data are calculated in the middle of the room and the cavity, while for the daylight illuminance values, the sensors layout is shown in Figure 4, providing three horizontal sensors, $\mathrm{H} 1, \mathrm{H} 2$ and $\mathrm{H} 3$, placed $0.85 \mathrm{~m}$ from the floor and spaced apart $0.70 \mathrm{~m}$. Figure 4 exhibits the layout of the simulated test facility with the relative position of the window and the second skin made with the new modules.
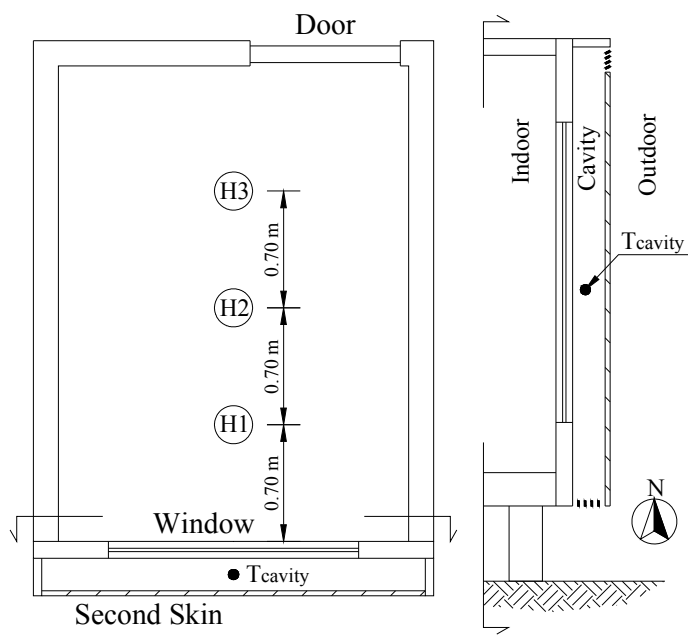

Figure 4: Layout of the simulated test facility as well as the daylight illuminances sensors.

\section{Methods}

The simulations are carried out considering the facility located in Naples (latitude $=40^{\circ} 51^{\prime} 46^{\prime \prime} 80 \mathrm{~N}$; longitude $=$ $\left.14^{\circ} 16^{\prime} 36^{\prime \prime} 12 \mathrm{E}\right)$. The specific EnergyPlus weather data file is considered to simulate the weather conditions of Naples. In order to guarantee a comfortable indoor air temperature at $20^{\circ} \mathrm{C}$ (in January) and $26^{\circ} \mathrm{C}$ (in July) an Electric Heat Pump (EHP), with Coefficient of Performance equal to 3.2 , is used to supply the heating and the cooling energy required by the facility. The simulations are performed considering operational both cooling and heating systems during the office time, from 9:00 to $18: 00$ in weekdays. 


\section{Energy analysis}

The energy comparison between the Base Case without the DSF (Case 0) and the other Proposed Cases including the DSF was performed in terms of primary energy consumption, using the index named Primary Energy Saving (PES):

$$
P E S=\left[\left(E_{p}^{B C}-E_{p}^{P C}\right) / E_{p}^{B C}\right] \cdot 100
$$

where $E_{p}^{P C}$ is the primary energy associated to the proposed cases and $\mathrm{E}_{\mathrm{p}}^{\mathrm{BC}}$ is the primary energy associated to the base case, both calculated as reported below:

$$
\begin{aligned}
& \mathrm{E}_{\mathrm{p}}^{\mathrm{PC}}=\left(\mathrm{E}_{\text {cooling }}^{\mathrm{PC}} / \mathrm{COP}+\mathrm{E}_{\text {heating }}^{\mathrm{PC}} / \mathrm{COP}\right) / \eta_{\mathrm{PP}} \\
& \mathrm{E}_{\mathrm{p}}^{\mathrm{BC}}=\left(\mathrm{E}_{\text {cooling }}^{\mathrm{BC}} / \mathrm{COP}+\mathrm{E}_{\text {heating }}^{\mathrm{BC}} / \mathrm{COP}\right) / \eta_{\mathrm{PP}}
\end{aligned}
$$

where:

$\mathrm{E}_{\text {cooling }}$ and $\mathrm{E}_{\text {heating }}$ are the cooling and the heating energy supplied to the facility, respctively;

COP is the coefficient of performance of the electric chiller serving the office and assumed equal to 3.2;

$\eta_{\mathrm{PP}}$ is the power plant average efficiency in Italy, including transmission losses (assumed equal to 0.42) (Ciampi et al., 2018).

\section{Environmental analysis}

The assessment of the environmental impact was performed in this study through an energy output-based emission factor approach (Chicco and Mancarella, 2008) in terms of global carbon dioxide equivalent emissions by means of the following indicator:

$$
\Delta \mathrm{m}_{\mathrm{CO}_{2}}=\mathrm{m}_{\mathrm{CO}_{2}}^{\mathrm{BC}}-\mathrm{m}_{\mathrm{CO}_{2}}^{\mathrm{PC}}
$$

where $\mathrm{m}_{\mathrm{CO}_{2}}^{\mathrm{PC}}$ is the mass of carbon dioxide equivalent emissions associated to the cases using the DSF and $\mathrm{m}_{\mathrm{CO}_{2}}^{\mathrm{BC}}$ is the mass of carbon dioxide equivalent emissions associated to the cases without the DSF.

The values of $\mathrm{m}_{\mathrm{CO}_{2}}^{\mathrm{PC}}$ and $\mathrm{m}_{\mathrm{CO}_{2}}^{\mathrm{BC}}$ used in Eq. 4 are computed as reported below:

$$
\begin{aligned}
& \mathrm{m}_{\mathrm{CO}_{2}}^{\mathrm{PC}}=\alpha \cdot\left(\mathrm{E}_{\text {cooling }}^{\mathrm{PC}} / \mathrm{COP}+\mathrm{E}_{\text {heating }}^{\mathrm{PC}} / \mathrm{COP}\right) \\
& \mathrm{m}_{\mathrm{CO}_{2}}^{\mathrm{BC}}=\alpha \cdot\left(\mathrm{E}_{\text {cooling }}^{\mathrm{PC}} / \mathrm{COP}+\mathrm{E}_{\text {heating }}^{\mathrm{PC}} / \mathrm{COP}\right)
\end{aligned}
$$

where $\alpha$ is the $\mathrm{CO}_{2}$ equivalent emission factor for electricity production. According to the values suggested Ciampi et al. (2018), referred to the Italian scenario, in this study, $\alpha$ is assumed equal to $573 \mathrm{~g}_{\mathrm{CO}_{2}} / \mathrm{kWh}_{\mathrm{el}}$.

\section{Visual analysis}

The evaluation of the visual performances of the proposed Cases in comparison with a conventional façade without the DSF is made through two indices for assessing visual comfort: the Useful Daylight Illuminance (UDI) (Nabil and Mardaljevic, 2006) and the Spatial Daylight Autonomy (sDA) (IES, 2012). Both indices were calculated considering the test facility as an office occupied from 9:00 to 18:00 in weekdays.

The UDI represent the fraction of the time for a specified period when the horizontal daylight illuminance values at a given point fall into a given range. Three ranges were defined by an upper and lower illuminance limit values, with the aim to identify three daylight level: (i) overlit, when the daylighting illuminance values are too high and they can cause visual discomfort; (ii) useful, when the daylight is able to supply a useful level of illuminance and (iii) underlit, when there is too little daylight. In the present paper, the daylight illuminance was considered useful when its values range from 100 lux to 2000 lux (Nabil and Mardaljevic, 2006).

The UDI index is calculated according to the equation (7); where $t_{j}$ is each occupied time in the specified period, $w f_{j}$ is a weighting factor, $E_{\text {Daylight }}$ are the horizontal illuminance values on a point and $\mathrm{E}_{\text {limit }}$ are the daylight illuminance limit values.

The Spatial Daylight Autonomy (sDA) is "the percent of an analysis area [...] that meets a minimum daylight illuminance level for a specified fraction of the operating hours per year" (IES, 2012). The sDA is evaluated according the following equation:

$s D A_{z / y \%}=\frac{\sum_{j} w f_{j} \cdot D A}{\sum_{j} p_{j}} \in[0,1]$ with $w f_{j}=\left\{\begin{array}{l}1 \text { if } \mathrm{DA} \geq \mathrm{DA}_{\text {limit }} \\ 0 \text { if } \mathrm{DA}<\mathrm{DA}_{\text {limit }}\end{array}\right\}$

where $\mathrm{z}$ is the reference illuminance level, $\mathrm{y} \%$ is the time fraction, $p_{j}$ are the points of the calculation grid and DA is the Daylight Autonomy. The Daylight Autonomy (DA) is calculated as:

$$
D A=\frac{\sum_{j} w f_{j} \cdot t_{j}}{\sum_{j} t_{j}} \in[0,1] \text { with } w f_{j}=\left\{\begin{array}{l}
1 \text { if } \mathrm{E}_{\text {Daylight }} \geq \mathrm{E}_{\text {limit }} \\
0 \text { if } \mathrm{E}_{\text {Daylight }}<\mathrm{E}_{\text {limit }}
\end{array}\right\}
$$

According to the recommendation of the Illuminating Engineering Society (IES), in this paper the $\mathrm{sDA}_{300 / 50 \%}$ is taken into account for daylight analyses. The $\mathrm{SDA}_{300 / 50 \%}$ expresses the percentage of analyzed points on which the horizontal daylight illuminance values exceed 300 lux for at least $50 \%$ of the occupied time.

\section{Results and discussion}

This section reports the simulation results associated to the cases described in Table 1 in comparison with those associated to the reference Case without the DSF, in terms of heating and cooling energy demand, Primary Energy Saving, $\mathrm{CO}_{2}$ equivalent emission avoided, Useful Daylight Illuminance and Spatial Daylight Autonomy in order to (i) establish their optimal configurations and (ii) identify the solution able to ensure the best performances. 


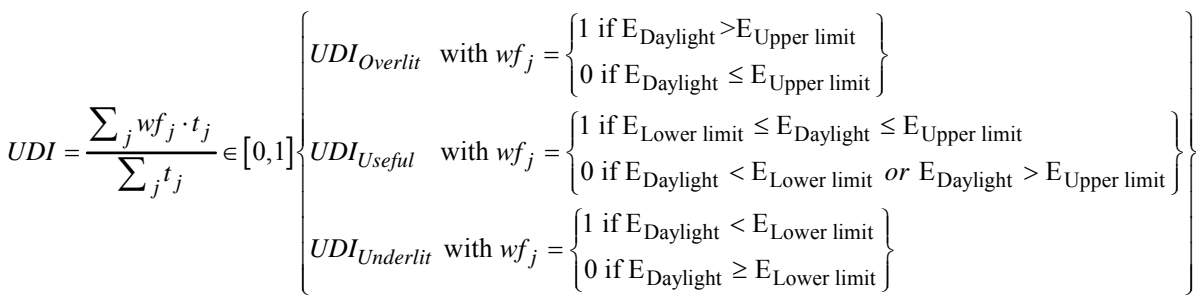

Figure 5 shows the cooling and the heating energy demand associated to the modelled facility for both January and July, upon varying the simulation cases.

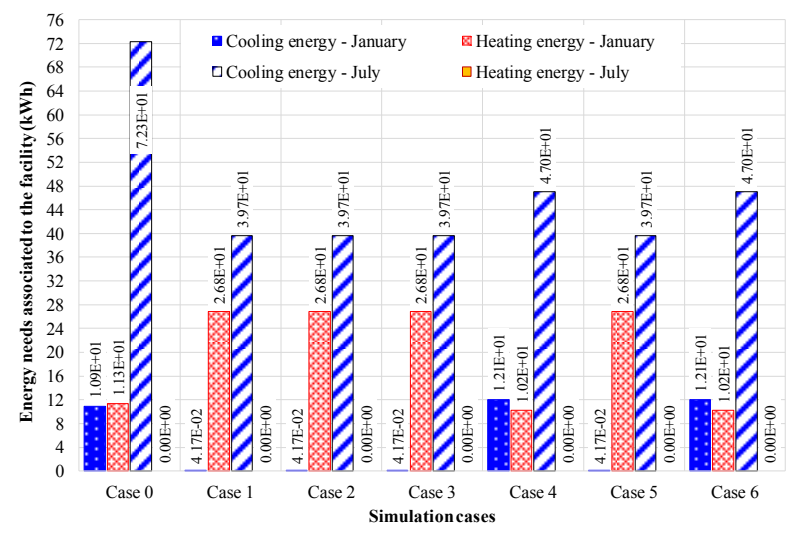

Figure 5: Cooling and Heating energy demand upon varying the simulation Case.

This figure highlights that:

- during January, in order to guarantee a comfortable indoor air temperature, it is necessary to provide cooling energy to the facility (in case of the indoor air temperature exceeding $26^{\circ} \mathrm{C}$ ) when the DSF in not installed (Case 0) and when the second skin is installed with a cavity depth equal to $10 \mathrm{~cm}$ for both ETFE (Case 4) and ETFE white (Case 6);

- during January, the heating energy needs are generally higher adding the DSF, with except for Cases 4 and 6 (with a reduction of about 9.4\%). However in the same simulation cases the cooling energy increases of about $10.4 \%$ in comparison with the Case 0 ;

- during July, whatever the material of the DSF and the cavity depth are, a reduction of the cooling energy is achieved in comparison to Case 0 (without the second skin), in particular this reduction ranges between 34.9\% (Cases 4 and 6) and 45.1\% (Cases 1, 2, 3 and $5)$.

Figure 6 reports the values of Primary Energy Saving (PES) and the mass of $\mathrm{CO}_{2}$ equivalent emission avoided $\left(\Delta \mathrm{m}_{\mathrm{CO}_{2}}\right)$, upon varying the simulation cases and simulation months.

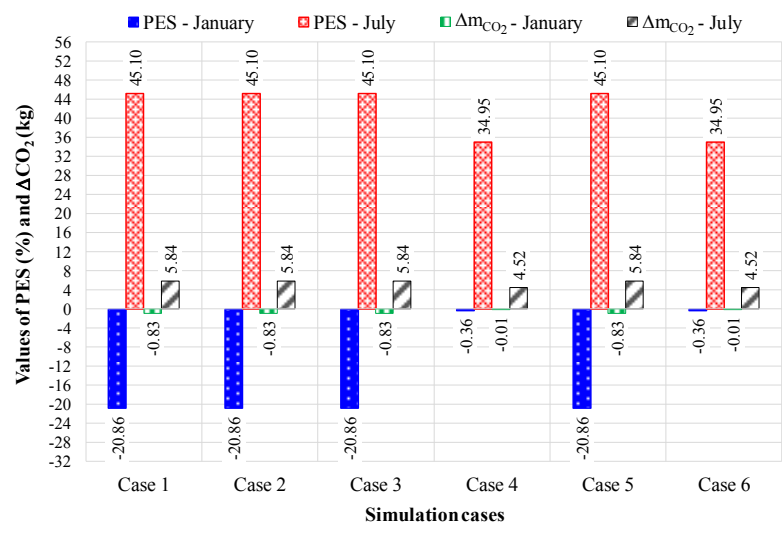

Figure 6: Values of PES and $\Delta m_{\mathrm{CO}_{2}}$ upon varying the simulation Case.

This figure indicates that:

- whatever the material of the DSF and the cavity depth are, the values of PES and $\Delta \mathrm{m}_{\mathrm{CO}_{2}}$ associated to the month of January are always negative; this means that the addition of the DSF does not allow to reduce neither the primary energy consumption nor the carbon dioxide equivalent emissions, with respect to the Case 0 (without the DSF);

- the worst performances (PES $=-20.86 \%$ and $\Delta \mathrm{m}_{\mathrm{CO}_{2}}=$ $-0.83 \mathrm{~kg}_{\mathrm{CO}_{2}}$ ) are achieved in the Cases $1,2,3$ and 5;

- whatever the simulation case is, the values of PES and $\Delta \mathrm{m}_{\mathrm{CO}_{2}}$ associated to the month of July are always positive; this means that using the DSF both the primary energy consumption as well as the carbon dioxide equivalent emissions are reduced, in comparison to the Case 0 (without the DSF);

- the best performances (PES $=45.10 \%$ and $\Delta \mathrm{m}_{\mathrm{CO}_{2}}=$ $5.84 \mathrm{~kg}_{\mathrm{CO}_{2}}$ ) are obtained in the Cases $1,2,3$ and 5.

Figures 7 and 8 exhibit the UDI values, evaluated respectively for January and July, on the sensors H1, H2 and $\mathrm{H} 3$, upon varying the simulation Cases. The UDI values were calculated during office hours, considering a comfort range between 100 lux and 2000 lux (Nabil and Mardaljevic, 2006).

From the Figure 7, it is possible to notice that:

- the presence of a second skin allows to reduce the

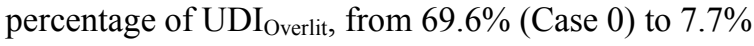
(Cases 5 and 6);

- the percentage of UDI Useful $_{\text {increase at the decreasing }}$ of the visual transmission values of the material used for second skin, ranging from 29.5\% (Case 0) to $74.4 \%$ (Cases 5 and 6); 
- the cavity depth does not influence the UDI values and

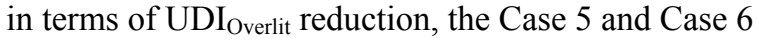
are the best arrangement for January (UDI $\mathrm{Uverlit}_{\text {equal }}$ to $7.7 \%$ )

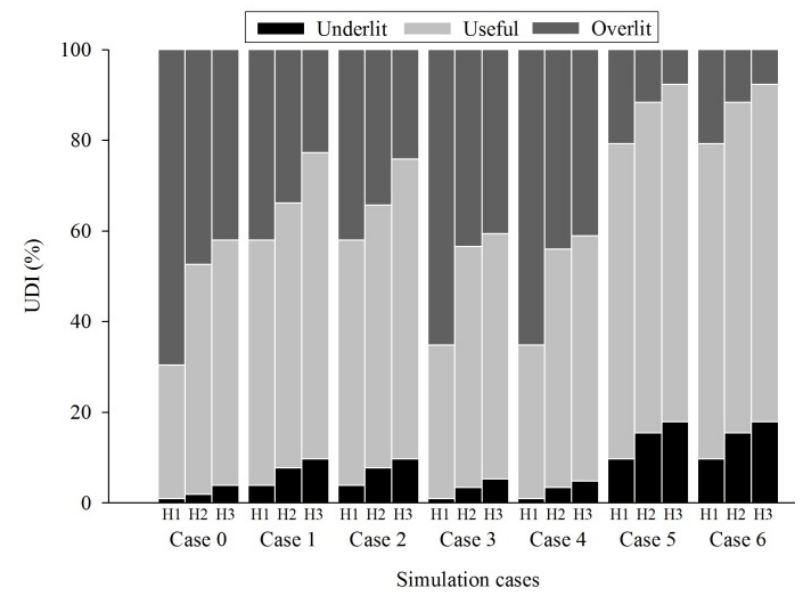

Figure 7: UDI values evaluated for January upon varying the simulation Case.

Figure 8 highlights that:

- the presence of a second skin allows to reduce the

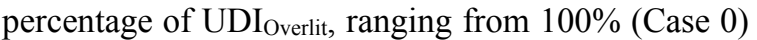
to $0 \%$ (Cases $1,2,5$ and 6$)$;

- the percentage of $\mathrm{UDI}_{\mathrm{Useful}}$ increases at the decreasing of the visual transmission values of the material used for second skin, ranging from $0 \%$ (Case 0 ) to $100 \%$ (Cases 1, 2, 5 and 6);

- the cavity depth does not influence the UDI values,

- the Cases 1,2, 5 and 6 allow to avoid the exceeding of the upper illuminance comfort threshold (2000 lux) on the sensors $\mathrm{H} 2$ and $\mathrm{H} 3$ and in terms of UDI $\mathrm{Overlit}$ reduction, the Case 5 and Case 6 are the best arrangement for July.

The differences observed in the UDI values distributions calculated for January and July illuminances can be explained considering the position of sun in the two months. Indeed, in January the maximum sun elevation angle of about $28^{\circ}$ allows a greater direct sunlight penetration inside the facility and then higher daylight illuminance values on the sensors than those calculated in July.

In the Table 2, the $\mathrm{sDA}_{300 / 50 \%}$ values calculated for all the simulation Cases, for both January and July, are listed. In this paper, the daylight is considered fulfilled if the illuminance values meet or exceed $300 \mathrm{~lx}$ for at least 50\% of the office hours $\left(\mathrm{sDA}_{300 / 50 \%}\right)$.

The values in the table states that: (i) the presence of a second skin in general implies a reduction of $\mathrm{sDA}_{300 / 50 \%}$ values while (ii) the cavity depth does not influence the visual index. The $\mathrm{SDA}_{300 / 50 \%}$ values reduction is emphasized during January, during which the $\mathrm{sDA}_{300 / 50 \%}$ values decrease from $90 \%$ (for the Case 0 ) to $68.1 \%$ (for the Cases 5 and 6). For July, only in the Cases 5 and 6, the $\mathrm{sDA}_{300 / 50 \%}$ values decrease to $99.7 \%$. From the table, it is possible to deduce that, in terms of $\mathrm{sDA}_{300 / 50 \%}$ optimization and excluding the
Case 0, the Case 3 and Case 4 are the best arrangement for both January and July.

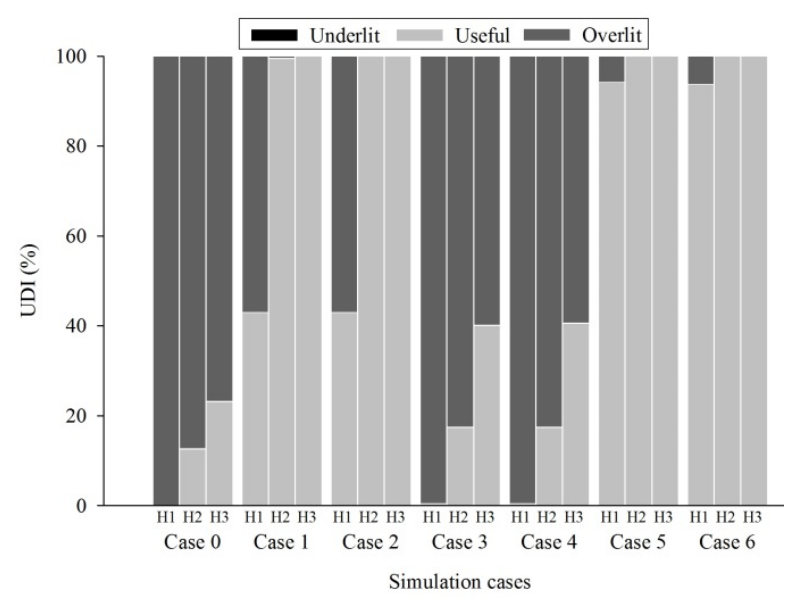

Figure 8: UDI values evaluated for July upon varying the simulation Case.

Considering the results reported in Figures 7 and 8 as well as in Table 2, from the visual point of view, the optimal configurations among the $\mathrm{UDI}_{\text {Overlit }}$ reduction, the $\mathrm{UDI}_{\text {Useful }}$ increasing and the $\mathrm{sDA}_{300 / 50 \%}$ optimization are:

- in January, Case 1 and Case 2;

- in July, Case 5 and Case 6.

Table 2: sDA values upon varying the simulation Case.

\begin{tabular}{|c|c|c|}
\hline Simulation case & $\begin{array}{c}\text { SDA300/50\% for } \\
\text { January (\%) }\end{array}$ & $\begin{array}{c}\text { SDA300/50\% for } \\
\text { July (\%) }\end{array}$ \\
\hline Case 0 & 90.0 & 100.0 \\
\hline Case 1 & 80.5 & 100.0 \\
\hline Case 2 & 80.5 & 100.0 \\
\hline Case 3 & 88.4 & 100.0 \\
\hline Case 4 & 88.4 & 100.0 \\
\hline Case 5 & 68.1 & 99.7 \\
\hline Case 6 & 68.1 & 99.7 \\
\hline
\end{tabular}

Table 3 summarizes the Double-Skin Façade optimal configurations from the energy and visual points of view. The table highlights that: (i) in general the optimal configurations are achieved using ETFE or ETFE white and (ii) only for July it is possible to identify the Case 5 ables to optimize both energy and visual performances.

Table 3: DSF optimal configurations.

\begin{tabular}{|c|c|c|}
\hline Simulation month & Visual analysis & Energy analysis \\
\hline January & Cases 1 and 2 & Cases 4 and 6 \\
\hline July & Cases 5 and 6 & Cases $1,2,3$ and 5 \\
\hline
\end{tabular}

\section{Conclusions}

In this paper the performances of new semi-transparent modules for the external layer of a DSF are investigated by means dynamic simulation software TRNSYS 17, coupled with the software Radiance. A sensitivity 
analysis is conducted upon varying the: (i) materials typology (Plastic Fabric, ETFE, ETFE white), (ii) cavity depth $(0.05 \mathrm{~m}$ and $0.10 \mathrm{~m})$ and (iii) transparency $(90.4 \%$, $33 \%$ and $25.8 \%$ ) of the materials used for these modules.

In particular, the analysis is carried out modelling a test facility on the base of a pair of future test facilities that are being built at the University of Campania "Luigi Vanvitelli" (Naples, Italy). On the South wall of the test facility virtual models, the simulation models of the new semi-transparent modules are added and arranged to realize a DSF. In order to evaluate the effect of different boundary conditions on the performances of the new modules, two months are considered, January and July for the winter and the summer, respectively.

The simulation results associated to the cases with the semi-transparent materials for the external layer of a DSF are compared with those associated to the conventional façade without the second skin assumed as reference. In particular, the following four indices are calculated: PES, $\Delta \mathrm{m}_{\mathrm{CO} 2}$, UDI and sDA. The performed analysis highlighted that:

- whatever the material of the DSF and the cavity depth are, the values of PES and $\Delta \mathrm{m}_{\mathrm{CO}_{2}}$ associated to the month of January are always negative (worst values of $\mathrm{PES}=-20.86 \%$ and $\Delta \mathrm{m}_{\mathrm{CO}_{2}}=-0.83 \mathrm{~kg}_{\mathrm{CO} 2}$ );

- whatever the simulation case is, the values of PES and $\Delta \mathrm{m}_{\mathrm{CO}_{2}}$ associated to the month of July are always positive (best values of PES $=45.10 \%$ and $\left.\Delta \mathrm{m}_{\mathrm{CO}_{2}}=5.84 \mathrm{~kg}_{\mathrm{CO}_{2}}\right)$;

- $\quad$ using the DSF the percentage of $\mathrm{UDI}_{\text {Overlit }}$ reduces from $69.6 \%$ up to $7.7 \%$ in winter and from $100 \%$ up to $0 \%$ in summer;

- the percentage of $\mathrm{UDI}_{\mathrm{Useful}}$ increases at the decreasing of the visual transmission values;

- $\quad$ using a second skin in general imply a reduction of $\mathrm{sDA}_{300 / 50 \%}$ values, while the cavity depth does not influence the visual index;

- the optimal configurations are usually achieved using ETFE or ETFE white;

- $\quad$ in July, the Case 5 can be identified as the best case able to optimize both energy and visual performances.

In future works, the modelled semi-transparent materials for the external layer of a DSF will be calibrated and validated based on experimental data and, then, they will be used to evaluate the impact of retrofit actions on existing buildings from energy, environmental and visual points of view.

\section{References}

Ahadi, M., Andisheh-Tadbir, M., Tam, M., Bahrami, M. (2016). An improved transient plane source method for measuring thermal conductivity of thin films: Deconvoluting thermal contact resistance. International Journal of Heat and Mass Transfer 96, 371-380.

Atzeri, A.M., Cappelletti, F., Tzempelikos, A., Gasparella. A. (2016). Comfort metrics for an integrated evaluation of buildings performance. Energy and Buildings 127, 411-424.

Baldinelli, G. (2009). Double skin façades for warm climate regions: Analysis of a solution with an integrated movable shading system. Building and Environment 44, 1107-1118.

Barbosa, S., Ip, K. (2014). Perspectives of double skin façades for naturally ventilated buildings: A review. Renewable and Sustainable Energy Reviews 40, 1019-1029.

Chicco, G., Mancarella, P. (2008). Assessment of the greenhouse gas emissions from cogeneration and trigeneration systems. Part I: models and indicators. Energy 33(3), 410-417.

Ciampi, G., Rosato, A., Scorpio, M., Sibilio, S. (2014). Energy performance of a residential buildingintegrated micro-cogeneration system upon varying thermal load and control logic. International Journal of Low-Carbon Technologies 11, 75-88.

Ciampi, G., Rosato, A., Scorpio, M., Sibilio, S. (2015). Energy and economic evaluation of retrofit actions on an existing historical building in the south of Italy by using a dynamic simulation software. Energy Procedia 78, 741-746.

Ciampi, G., Rosato, A., Sibilio, S. (2018). Thermoeconomic sensitivity analysis by dynamic simulations of a small Italian solar district heating system with a seasonal borehole thermal energy storage. Energy 143, 757-771.

Cremers, J. (2014). Environmental impact of membrane and foil materials and structures - status quo and future outlook. Technical transactions Architecture $7 A, 39-51$.

De Michele, G., Oberegger, U.F., Baglivo, L. (2014). Coupling dynamic energy and daylighting simulations for complex fenestration systems. Proceedings of the Building Simulation Applications BSA2015 - 2nd IBPSA-Italy conference. Bozen-Bolzano (IT), 4 - 6 February 2015.

EnergyPlus. Weather data, EnergyPlus energy simulation software.

http://apps1.eere.energy.gov/buildings/energyplus/.

Gratia, E. , De Herde, A. (2007). The most efficient position of shading devices in a double-skin façade. Energy and Buildings 39, 364-373.

Hoseini, A.G., Hoseini, A.G., Berardi, U., Tookey, J., Hin Wa Li, D., Kariminia, S. (2016). Exploring the advantages and challenges of double-skin façades (DSFs). Renewable and Sustainable Energy Reviews 60, 1052-1065.

Illuminating Engineering Society, IES. (2012). Approved Method: IES Spatial Daylight Autonomy(sDA) and Annual Sunlight Exposure (ASE). 
Kuhn, T.E. (2017). State of the art of advanced solar control devices for buildings. Solar Energy 154, 112133.

Mainini, A.G., Poli, T., Paolini, R., Zinzi, M., Vercesi, L. (2014). Transparent multilayer ETFE panels for building envelope: thermal transmittance evaluation and assessment of optical and solar performance decay due to soiling. Energy Procedia 48, 1302 1310.

Mainini, A.G., Speroni, A., Zani, A., Poli, T. (2016). The effect of water spray systems on thermal and solar performance of an ETFE panel for building envelope. Procedia Engineering 155, 352 - 360.

Monticelli, C., Campioli, A., Zanelli, A. (2009). Environmental load of ETFE cushions and future ways for their self-sufficient performances. Proceedings of the International Association for Shell and Spatial Structures (IASS) Symposium. Valencia (ES), 28 September - 2 October 2009.

Nabil, A. and Mardaljevic, J. (2006). Useful daylight illuminances: A replacement for daylight factors. Energy and Buildings 38(7), 905-913.

Paech, C. (2016). Structural membranes used in modern building facades. Procedia Engineering 155, 61 - 70.

Pomponi, F., Piroozfar, P.A.E., Southall, R., Ashton, P., Farr, E.R.P. (2016). Energy performance of DoubleSkin Façades in temperate climates: A systematic review and meta-analysis. Renewable and Sustainable Energy Reviews 54, 1525-1536.

Radiance. A Validated Lighting Simulation Tool. https://www.radiance-online.org.

SketchUp. 3D modelling for everyone. https://www.sketchup.com.

Su2rad. A SketchUp plugin to export SketchUp scene geometry to the Radiance daylight simulation tool. https://tbleicher.github.io/su2rad/.

Trnsys 3D. A SketchUp to input the geometric information and view the results. https://rnsys.de/docs/trnsys $3 \mathrm{~d} /$ trnsys $3 \mathrm{~d}$ _uebersicht_e n.htm.

TRNSYS 17. A Transient System Simulation Tool. http://www.trnsys.com.

WINDOW. A computer program for calculating total window thermal performance indices. https://windows.lbl.gov/software/window. 